\title{
An analytical study of critical factors affecting contractor efficiency in construction projects in Indian scenario
}

DOI 10.2478/otmcj-2018-0010

Received March 31, 2018; accepted July 23, 2018

\begin{abstract}
Purpose: Recent studies show that lowest bidder technique is mainly used in developing countries such as India to award a contract. It has been demonstrated that the lowest bid is not always the accurate one and can lead to cost overruns and time extensions amongst other problems. The aim of this study was to investigate the critical factors impacting contractor's efficiency in Indian construction projects.
\end{abstract}

Research approach: A survey was sent to participants of construction projects awarded by the government with the lowest bidder technique in Uttar Pradesh, India. For further research, snowball sampling was used, and structured interviews were conducted amongst experienced managers and engineers of these projects on both client's and contractor's side.

Findings: It was observed that, to a greater extent, the delays were caused due to contractor's opportunistic behaviour. The main findings are that new bidding methodologies are to be tested as they can lead to the choice of a more accurate and realistic bidder. In addition, subjective evaluation components, such as schedule and workforce, should be reflected in contract award methods in addition to the cost criteria. Further studies should be performed on the choice of contract awarding methodology based on the project size and type.

Originality value: The researcher's focus was to analyze the influence of contracting methodologies and factors

\footnotetext{
*Corresponding author: Shumank Deep, University of Newcastle, Newcastle, NSW, Australia, E-mail: shumank2012@gmail.com Laura Simon, Ali Rahimzadeh and Sulala Al-Hamdani, School of Architecture and Built Environment, University of Newcastle, Callaghan, NSW 2308, Australia

Mohd Asim, Department of Civil Engineering, Himalayan Institute of Technology and Management, Lucknow, India
}

affecting contractor's performance in lowest bid award project, where this is an area of least focus amongst researchers in the Indian subcontinent.

Keywords: project management, construction industry, contractor performance, construction management

\section{Introduction}

The latest and complex modifications in projects and market have compelled the researchers to study the feasibility of project delivery methods used in the construction industry (Palaneeswaran and Kumaraswamy, 2001). Lowest bid award methodology is one of the most popular bidding techniques used for project award. Increased application of lowest bidder technique has promoted inadequacy and unseemliness amongst the submitted bids and resulted in the repetitive occurrence of disputes, cost overruns and time extension (Leśniak, 2015; Setiawan et al., 2015; Suprapto et al., 2015a; Chang, 2017; Yang et al., 2017). As a result, if the Indian government and its subsidiaries as well as privately managed construction organizations have learned a lesson, have adapted to recent advances and invite worthy bidders, yet it is still important to research prequalification criteria and the target of the prequalification and bid assessment forms (Hatush and Skitmore, 1997).

Although in the past few years, in developing countries especially in Uttar Pradesh, India, it is a common observation that construction activities being conducted by government and its subsidiary agencies prefer lowest bidder techniques to award a project for medium-scale projects. The contractor whose bidding price is the lowest will win the bid (Manu et al., 2015; Dražić et al., 2016; Elzomor and Parrish, 2016; Deep et al., 2017a; Dixit et al., 2017). The prequalification and bid assessment methods require the advancement of essential and adequate selection criteria 
(Palaneeswaran and Kumaraswamy, 2000). The past two decades have witnessed an enormous improvement in multidimensional aspects of project requirements which prompted to the utilization of different project delivery frameworks (Deep et al., 2017a, 2017e). Interestingly, the prequalification and bid assessment and handling, evaluating and appraisal of criteria are still in its unique frame. In the current scenario, the lowest bidder from the past project is collected in a pool and considered for prequalification in a project, but still lowest bid award is a preferred mechanism to award projects.

\section{Theoretical background}

The quality of work in the public sector is affected, to a greater extent, by the capability of the contractor (Wong, 2004; Elyamany and Abdelrahman, 2010; Chang, 2016). Researchers have arrived at a consensus that client satisfaction is the vital factor to be considered for contractor's performance measurement "clients are at the core of the process and their needs must be met by the industry" (Latham, 1994; Xiao and Proverbs, 2003). Whether it is arm's length or long term, a client is generally focused on the factors such as budget, time and quality (Heesom et al., 2003; Chang, 2016). The construction industry is considered to be a dynamic and sophisticated; the pertinent reason is it has a direct impact on public (Wong, 2004; Gündüz et al., 2012; Chang, 2015). In addition, major construction projects involve various categories of resources, i.e. human resources, materials and equipment, which require effective planning and allocation by contractors to avoid stereotypes and reap maximum economic benefits (Sarker et al., 2012).

It is a well-established fact for the lowest bid award method that the absence of competition, unreasonable time extensions, trading off quality and acceleration of project costs are the significant issues related to the current approach of conveying projects (Lema, 2006). Inadequate financing of the project by the contracting organization and underestimated procurement of materials, equipment and workforces are prime causes for delays amid the construction stage in the construction industry (Lema, 2006; Oduro-Owusu et al., 2010; Khan et al., 2017c; Singh et al., 2017b).

The construction procedure includes the hierarchical flow of information. Strife and question can hence exist at all levels in the contractual hierarchy amongst client and consultant, client and contractor and contractor and subcontractor. Amongst many reasons for contradictions in the construction project, the project delivery framework chose one of the significant components (Deep et al., 2017e). Henceforth, numerous researchers have stated that construction organizations have learned from their past experiences and made various advancements. Research findings have created modified techniques to address these issues (Safa et al., 2015; Asgari et al., 2016; Aitken and Paton, 2017; Asim et al., 2017b; Deep et al., 2017a, 2017e).

One of these findings, focused normal bidding strategy, has turned into the most favoured approach amongst numerous European nations. Its enactment permitted public sector clients to diminish the unfriendly impacts of abnormally low tenders (ALTs), including unsuitable quality through the need to decrease construction costs (Winch, 2000), savage valuing, out-of-line rivalry that misshapes the market and contrarily influencing alternate bidders (Deep et al., 2017a). Focused normal bidding strategy has turned out to be the most preferred since all the components of the open competitive system are retained on the one hand. Thus, the probability of being awarded a contract to a contractor who submits, either unintentionally or intentionally, an unreasonably low bid will be decreased (Leśniak, 2015; Suprapto et al., 2015a, 2015b; Erdogan et al., 2017). The opposition gives an approach to keep away from extortion and defilement, which are the significant downsides of other transaction-based options.

\section{Identification of knowledge gap}

There are distinct advantages and disadvantages to the low-bid award framework. Increased competition amongst contractors is a distinct advantage of the procedure. It compels the contractors to decrease quoted costs for carrying out specific work, more often than not through advancement, to guarantee they win bids and keep up their net revenues (Wahaj et al., 2017a). Furthermore, the procedure is beneficial, specifically to the client on account of its straight forwardness, a necessary foundation of the transparency and increased professionalism (Ioannou and Leu, 1993; Ng et al., 2002; Walker et al., 2002; Shehu and Akintoye, 2010; Ishii et al., 2014; Kotula et al., 2015; Naoum and Egbu, 2015; Suprapto et al., 2015b; Jaafar et al., 2016; Wang et al., 2016; Bai et al., 2017). However, the system is not as advantageous in the case of lowest bid award to carry out a particular task that has inherent imperfections (Jekale, 2004; Deep et al., 2017d, 2018).

The framework is entirely focused towards client's requirement which is not a bad idea; since it is more popular with government and its subsidiaries, it tends to increase malpractices and poor quality due to the contractors being sceptical about their profit margins (Deep et al., 2017b, 2017c, 2017e, Mathivathanan et al., 2017; Mishra et al., 2017; Sanderson et al., 2017). The criterion for choosing 
the potential bidder is the bid that is reasonably below the client's estimate and serves client's interest well (Deep et al., 2017e). Thus, there is a clear research gap, in the case of developing countries, that the contract awarding framework fails to answer mutual interests of client and contractor relationship resulting in unavoidable risks (Asim et al., 2017a, 2017b; Deep et al., 2017a, 2017b; Khan et al., 2017b; Singh et al., 2017a; Wahaj et al., 2017b). This study aimed to identify the critical factors of contract awarding methodologies that tend to decrease contractors' efficiency in India.

\section{Research approach}

The work presented in this article is a result of exhaustive independent research conducted for a period of 5 months, i.e. August 2016 to December 2016. The target areas of the research were projects, in which Uttar Pradesh, India, was awarded by using lowest bidder technique. The information of these projects was obtained using Government of India, Right to Information Act, 2005. There were overall 400 major or minor construction projects being conducted throughout the state.

The required number of responses was determined by the following formula (Israel, 1992; Damoah and Akwei, 2017):

$$
n=\frac{N}{1+N e^{2}}
$$

where $n$ is the required number response, $e^{2}$ is the error limit and $\mathrm{N}$ is the sample size.

The level of confidence was assumed as 95\%, and an error margin of $5 \%$ was assumed. A total of 172 responses were required for the assessment of required parameters.

All participants were required to rate their answers on a Likert scale of $1-5$. For determining the critical factors that affected the project, we used importance index analysis and ranking and percentile analysis. For further research, snowball sampling was used, and structured interviews were conducted amongst the professionals working in the top level and middle level of hierarchy amongst the project staff on both client's and contractor's side as summarized in Tabs. 2 and 3.

\section{Data analysis}

An extensive study of literature resulted in the identification of various factors that affected contractor's efficiency
Tab. 1: Categorization of the factors affecting contractor's efficiency in construction projects.

\begin{tabular}{llr}
\hline Sl. no. & Category item & $\begin{array}{l}\text { Total no. of } \\
\text { category factors }\end{array}$ \\
\hline 1 & Consultant's influence & 8 \\
2 & Contractor's issues & 13 \\
3 & Design changes & 11 \\
4 & Equipment related & 7 \\
5 & External factors & 17 \\
6 & Human resources & 9 \\
7 & Material constraints & 9 \\
8 & Non-cooperation from principal & 19 \\
9 & Project complexities & 6 \\
& Total & 99 \\
\hline
\end{tabular}

Tab. 2: Categorization of participants.

\begin{tabular}{|c|c|c|c|}
\hline ID & $\begin{array}{l}\text { Affiliation of } \\
\text { respondents }\end{array}$ & $\begin{array}{l}\text { No. of } \\
\text { respondents }\end{array}$ & Percentage \\
\hline 1 & Principal & 4 & 1.45 \\
\hline 2 & Consultants & 20 & 7.27 \\
\hline 3 & Managers & 44 & 16.00 \\
\hline 4 & Engineers & 82 & 29.82 \\
\hline \multirow[t]{2}{*}{5} & Contractors & 125 & 45.46 \\
\hline & Total & 275 & 100 \\
\hline
\end{tabular}

Tab. 3: Working experience of respondents.

\begin{tabular}{lrr}
\hline Industrial experience & No. of respondents & Percentage \\
\hline $1-5$ years & 42 & 15.27 \\
$5-10$ years & 58 & 21.09 \\
$10-0$ years & 86 & 31.27 \\
Above 20 years & 89 & 32.37 \\
Total & 275 & 100 \\
\hline
\end{tabular}

shown in the Tab. 1. and relative importance index of each factor was calculated. Furthermore, all these nine categories were divided into 99 different factors.

\subsection{Ranking of delay factors}

After calculating overall index (OI) for each delay factor, a ranking of delay factors was carried out by their OI, which is summarized in Appendix 1. It was found that the OI was the highest for factor number 43, "Delay in obtaining permits from municipality" (72.49\%), related to the external category. Factor number 63, "Human Resources strikes due to revolutions" (48.82\%), related to human resources category, was the lowest amongst all factors. This indicates that factor number 43 is the most influencing 
parameter and factor number 63 is the least influencing parameter of construction delay in India. From the list of 99 delay factors, top 20 major delay factors and least 20 delay factors are selected considering the OI factors (Ibironke et al., 2013).

\section{Discussion of results}

Evidently, all the delay-causing factors originated either from the following: consultant's influence, contractor's issues, design changes, equipment related, external factors, human resources, material constraints, non-cooperation from principal or project complexities (Eriksson, 2010; Wang et al., 2015; Doğan et al., 2016; Sinčić Ćorić et al., 2017). A probable explanation of this is every actor is trying to blame others for delays. Furthermore, it is desirable to compare the strength or importance of each category; thus, a weighted average of each category was calculated to arrive at an unbiased observation. The results

Tab. 4: Equivalent average relative importance index of category.

\begin{tabular}{llr}
\hline Rank & Category item & $\begin{array}{l}\text { Equivalent average } \\
\text { relative importance } \\
\text { index (Eq. 2) }\end{array}$ \\
\hline 01 & Consultant's influence & 64.62 \\
02 & Contractor's issues & 63.82 \\
03 & Design changes & 62.46 \\
04 & Equipment related & 62.28 \\
05 & External factors & 60.28 \\
06 & Human resources & 60.26 \\
07 & Material constraints & 60.25 \\
08 & Non-cooperation from & 59.61 \\
09 & principal & 59.31 \\
\hline
\end{tabular}

are presented in Tab. 4 by using priority rule formula as shown in the following equation:

$$
\text { ERII }_{\mathbf{j}}(\%)=\left(\frac{\sum_{n=1}^{n=N}(P n X \text { RIIn })}{\sum_{n=1}^{n=N}(P n)}\right)
$$

where $\mathrm{ERII}_{\mathrm{j}}(\%)$ is the equivalent weighted average percentage of relative importance index per category and ORII $_{n}(\%)$ is the overall weighted average percentage of relative importance index of each factor in a specific category, which is calculated on the basis of total experiences of respondents; $\mathrm{n}$ is the number that represents the factor number in the related category (from the first factor of category $n=1$ to form the last factor of category $n=N$ ) and $P_{n}$ is the priority weight of the studied factor. It is clear that the results of the nine categories are almost consistent, where the categories are ranked from top to bottom as summarized in Tab. 4.

As evident from Tab. 5, summarizing the rank and impact of the grouped factors, there were three most contributing factors to delay for each group: the first important group was consultant's influence (Equivalent average Relative Importance Index (EARII) $=64.62 \%$ ), the most critical factor in this category was "inadequate project management assistance $(\mathrm{OI}=66.17)$ ". The second important group was contractor's issues having the most significant factor as "inadequate contractor experience (OI=70.23)". The third most important group was design group (design changes) having the most important factor in this category as "misinterpretation of owner's requirements by design engineer (OI=72.03)"; this factor mostly depended on the skill of engineer and designers. The OI and ranks of the each factors are summarized in Appendix 1.

As it can be observed from the abovementioned findings, most of the factors that have been prioritized by the participants are related to the contractor. The reason is as

Tab. 5: High priority delay factors in each category.

\begin{tabular}{|c|c|c|c|c|c|}
\hline Category no. & Category & ID & Delay factor description & $01 \%$ & Overall rank \\
\hline 1 & Consultant & 6 & Inadequate project management assistance & 66.17 & 19 \\
\hline 2 & Contractor & 10 & Inadequate contractor experience & 70.23 & 05 \\
\hline 3 & Design & 28 & Misinterpretation of owner's requirements by design engineer & 72.03 & 03 \\
\hline 4 & Equipment & 37 & Low efficiency of equipment & 66.07 & 21 \\
\hline 5 & External & 43 & Delay in obtaining permission & 72.30 & 01 \\
\hline 6 & Human resources & 61 & Shortage of human resources & 72.30 & 02 \\
\hline 7 & Material & 67 & Damage of sorted materials & 66.83 & 13 \\
\hline 8 & Owner & 78 & Delayed payments & 67.03 & 12 \\
\hline 9 & Project & 94 & Project ambiguities (project type, project scale, etc.) & 67.51 & 10 \\
\hline
\end{tabular}

Ol, overall index. 
follows: although a contractor is awarded project on the basis of its low bid, it tends to meet out its finances through time value on money, i.e. by delaying the project (Hatush and Skitmore, 1997; Palaneeswaran and Kumaraswamy, 2000, 2001; Elyamany and Abdelrahman, 2010; Sarker et al., 2012; Leśniak, 2015; Deep et al., 2017e; Asim et al., 2017a, 2017b). The real purpose behind quality imperfections, i.e. in the case of equipment and material, has been due to the inclination of contractors to meet out their cost since they have won the tender with low bids. It is found in the research that the advance according to the timetable of most projects awarded on the responsive lowest bidder award system was weak (Deep et al., 2017e). Competitive lowest bid method has been exceptionally scrutinized for its adverse effect on contractor's profit, disputes/claims, coordination, quality control and project span. Respondents exceedingly valued other option bidding methodologies incorporated into the review for their beneficial outcomes on these characteristics. Most of the respondents favored the use of a competitive system ensuring the work award to bidder whose bid is closest to the average of all bids. (Asim et al., 2017b; Deep et al., 2017a, 2017e; Khan et al., 2017a, 2017c; Singh et al., 2017b; Wahaj et al., 2017a). Amongst the respondents, however, few trusted that the current bidding strategy does not urge contractors to be innovative. The majority of the respondents have consented to the application of competitive system with an arrangement to award contracts to bidders closest to the normal of all bidders and the project cost. All respondents trusted that bidding strategy ought to rely on sort and multifaceted nature of the project. The majority of the members agreed that subjective evaluation components (e.g. timetable, association and workforce) other than cost should be reflected in the contract award. In addition, the majority of the respondents agreed that the choice of the bid evaluation and the contract award methods depend on the type of contract chosen.

\section{Conclusion}

The method of procurement for the construction project is significant for its success (Shehu and Akintoye, 2010; Kotula et al., 2015; Doğan et al., 2016; Wahaj et al., 2017b), since its essential determinant for the selection of participant that will be responsible for its execution. It was observed that, in Indian scenario, mainly consultant's influence and contractor's influence are the major factors that affect contactor's working efficiency in state-funded construction. Regarding the efficiency of the contractor, it was observed that there is a lack of coordination between consultant and contractor indicating the presence of opportunism. A reason for opportunistic behaviours is the lack of experience of the contractor on a similar type of projects. Next, we observed in this study that there is a lack of project management awareness. In the current state, it is only reduced to planning stage and implementation is low or negligible in execution. Thus, it is vital for a contractor to adopt best practices in project management and for a planner to improve their tendering strategies to ensure on-time delivery of construction projects which will enhance the contractor's efficiency in construction projects.

\section{References}

Aitken, A., \& Paton, R. A. (2017). The ‘t-shaped buyer': A transactional perspective on supply chain relationships. Journal of Purchasing and Supply Management, 23(4), pp. 280-289. doi: 10.1016/j.pursup.2017.03.001.

Asgari, S., Awwad, R., Kandil, A., \& Odeh, I. (2016). Impact of considering need for work and risk on performance of construction contractors: An agent-based approach. Automation in Construction, 65, pp. 9-20. doi: 10.1016/j. autcon.2016.01.004.

Asim, M., Deep, S., \& Ahmad, S. A. (2017a). Time impact study of real estate sector construction projects post application of lean principles for delay resolutions. Indian Journal of Science and Technology, 8(82), pp. 89-99.

Asim, M., Deep, S., \& Ahmad, S. A. (2017b). Time impact study of real estate sector construction projects post application of lean principles for delay resolutions. International Journal of Civil Engineering and Technology, 8(2), pp. 89-99.

Bai, C., Rezaei, J., \& Sarkis, J. (2017). Multicriteria green supplier segmentation. IEEE Transactions on Engineering Management, 64(4), pp. 515-528.

Chang, J.-R. (2015). Performance records system for public construction contractors-application of smooth roads project. Journal of Performance of Constructed Facilities, 30(3), p. 06015004.

Chang, J.-R. (2016). Performance records system for public construction contractors \&\#x2014;application of smooth roads project. Journal of Performance of Constructed Facilities, 30(3), doi: 10.1061/(ASCE)CF.1943-5509.0000793.

Chang, J. (2017). The effects of buyer-supplier's collaboration on knowledge and product innovation. Industrial Marketing Management, 65, pp. 129-143. doi: 10.1016/j. indmarman.2017.04.003.

Damoah, I. S., \& Akwei, C. (2017). Government project failure in Ghana: A multidimensional approach. International Journal of Managing Projects in Business, 10(1), pp. 32-59.

Deep, S., Asim, M., \& Ahmad, S. A. (2017a). Earned value based liability calculation algorithm for schedule delays in construction projects. Indian Journal of Science and Technology, 10(15), pp. 1-10. 
Deep, S., Asim, M., \& Khan, M. K. (2017b). Review of various delay causing factors and their resolution by application of lean principles in India. Baltic Journal of Real Estate Economics and Construction Management, 5(1), pp. 101-117.

Deep, S., Jefferies, M., \& Gajendran, T. (2017c). Resolving constraints in collaborative procurement through the lens of a portfolio purchasing model: A traditional literature review. Paper presented at the International Symposium on Frontiers of Infrastructure Finance, Indian Institute of Technology, Kharagpur.

Deep, S., Khan, M. B., Ahmad, S., \& Saeed, A. (2017d). A study of various factors affecting contractor's performance in lowest bid award construction projects. International Journal of Civil Engineering and Technology, 8(2), pp. 28-33.

Deep, S., Singh, D., \& Ahmad, S. (2017e). A review of contract awards to lowest bidder in Indian construction projects via case based approach. Open Journal of Business and Management, 5(1), pp. 159-168.

Dixit, V., Chaudhuri, A., \& Srivastava, R. K. (2017). Procurement scheduling in engineer procure construct projects: A comparison of three fuzzy modelling approaches. International Journal of Construction Management, 18, pp. 1-18. doi: 10.1080/15623599.2017.1314750.

Doğan, S. Z., Çalğici, P. K., Arditi, D., \& Günaydin, H. M. (2016). Critical success factors of partnering in the building design process. METU Journal of the Faculty of Architecture, 32(2).

Dražić, J., Peško, I., Mučenski, V., Dejić, A., \& Romanovich, M. (2016). Evaluating contractors and offered structural solution. Procedia Engineering, 165, pp. 898-905. doi: 10.1016/j. proeng.2016.11.790.

Elyamany, A., \& Abdelrahman, M. (2010). Contractor performance evaluation for the best value of superpave projects. Journal of Construction Engineering and Management, 136(5), pp. 606-614. doi: 10.1061/(ASCE)C0.1943-7862.0000158.

Elzomor, M., \& Parrish, K. (2016). Investigating building construction process and developing a performance index. Procedia Engineering, 145, pp. 211-218. doi: 10.1016/j. proeng.2016.04.063.

Erdogan, S. A., Šaparauskas, J., \& Turskis, Z. (2017). Decision making in construction management: AHP and expert choice approach. Procedia Engineering, 172, pp. 270-276. doi: 10.1016/j.proeng.2017.02.111.

Eriksson, P. E. (2010). Partnering: What is it, when should it be used, and how should it be implemented? Construction Management and Economics, 28(9), pp. 905-917.

Gündüz, M., Nielsen, Y., \& Özdemir, M. (2012). Quantification of delay factors using the relative importance index method for construction projects in turkey. Journal of Management in Engineering, 29(2), pp. 133-139.

Hatush, Z., \& Skitmore, M. (1997). Assessment and evaluation of contractor data against client goals using pert approach. Construction Management \& Economics, 15(4), pp. 327-340.

Heesom, D., Xiao, H., and Proverbs, D.G. (2003). The development of appropriate measurements for the international comparison of contractor performance. Paper presented at the Construction Research Congress. Available at http://ascelibrary.org/doi/ abs $/ 10.1061 / 40671 \% 282003 \% 2919$

Ibironke, O. T., Oladinrin, T. O., Adeniyi, O., \& Eboreime, I. V. (2013). Analysis of non-excusable delay factors influencing contractors' performance in Lagos state, Nigeria. Journal of Construction in Developing Countries, 18(1), pp. 53-72. Ioannou, P. G., \& Leu, S.-S. (1993). Average-bid methodcompetitive bidding strategy. Journal of Construction Engineering and Management, 119(1), pp. 131-147.

Ishii, N., Takano, Y., \& Muraki, M. (2014). An order acceptance strategy under limited engineering man-hours for cost estimation in engineering-procurement-construction projects. International Journal of Project Management, 32(3), pp. 519-528.

Israel, G. D. (1992). Determining Sample Size. University of Florida Cooperative Extension Service, Institute of Food and Agriculture Sciences, EDIS Gainesville.

Jaafar, M., Nuruddin, A. R., \& Bakar, S. P. S. A. (2016). Managerial capabilities of housing developers: Building the competitive advantage of a firm. International Journal of Construction Management, 16(1), pp. 27-38.

Jekale, W. (2004). Performance for Public Construction Projects in Developing Countries: Federal Road and Educational Building Projects in Ethiopia. Thesis, Norwegian University of Science \& Technology.

Khan, A. R., Deep, S., \& Asim, M. (2017a). Analysis of maintenance records of construction equipments and their importance in minimizing equipments breakdown during project execution phase to lessen time overrun. International Journal of Civil Engineering and Technology, 8(83), pp. 11-23.

Khan, M. A., Deep, S., Asim, M., \& Khan, Z. R. (2017b). Quantization of risks involved in supply of ready mix concrete in construction industry in Indian scenario. International Journal of Civil Engineering and Technology, 8(3), pp. 175-184.

Khan, M. A., Srivastava, S. D., Asim, M., \& Khan, Z. R. (2017c). Quantization of risks involved in supply of ready mix concrete in construction industry in Indian scenario. International Journal of Civil Engineering and Technology, 8(3), pp. 175-184.

Kotula, M., Ho, W., Dey, P. K., \& Lee, C. K. M. (2015). Strategic sourcing supplier selection misalignment with critical success factors: Findings from multiple case studies in Germany and the United Kingdom. International Journal of Production Economics, 166, pp. 238-247.

Latham, S. M. (1994). Constructing the Team. HM Stationery Office, London.

Lema, M. (2006). Alternative Project Delivery Methods for Public Constructions: Cases in Oromia Region. Addis Ababa University, Addis Ababa.

Leśniak, A. (2015). Reliability assessment of research into contractors' bidding decisions. Procedia Engineering, 122, pp. 251-257. doi: 10.1016/j.proeng.2015.10.033.

Manu, E., Ankrah, N., Chinyio, E., \& Proverbs, D. (2015). Trust influencing factors in main contractor and subcontractor relationships during projects. International Journal of Project Management, 33(7), pp. 1495-1508. doi: 10.1016/j. ijproman.2015.06.006.

Mathivathanan, D., Kannan, D., \& Haq, A. N. (2017). Sustainable supply chain management practices in Indian automotive industry: A multi-stakeholder view. Resources, Conservation and Recycling, 128(01), pp. 284-305. doi: 10.1016/j. resconrec.2017.01.003.

Mishra, D., Gunasekaran, A., Papadopoulos, T., \& Hazen, B. (2017). Green supply chain performance measures: A review 
and bibliometric analysis. Sustainable Production and Consumption, 10, pp. 85-99.

Naoum, S., \& Egbu, C. (2015). Critical review of procurement method research in construction journals. Procedia Economics and Finance, 21, pp. 6-13. doi: 10.1016/s2212-5671(15)00144-6.

Ng, S. T., Luu, D. T., Chen, S. E., \& Lam, K. C. (2002). Fuzzy membership functions of procurement selection criteria. Construction Management and Economics, 20(3), pp. 285-296. doi: 10.1080/01446190210121288.

Oduro-Owusu, K., Fugar, F., \& Manteau, K. (2010). Factors influencing construction worker job satisfaction in the Ghanaian construction industry. Unpublished MSc thesis, KNUST.

Palaneeswaran, E., \& Kumaraswamy, M. (2001). Recent advances and proposed improvements in contractor prequalification methodologies. Building and Environment, 36(1), pp. 73-87.

Palaneeswaran, E., \& Kumaraswamy, M. M. (2000). Contractor selection for design/build projects. Journal of Construction Engineering and Management, 126(5), pp. 331-339.

Safa, M., Shahi, A., Haas, C. T., Fiander-McCann, D., Safa, M., Hipel, $\mathrm{K}$., et al. (2015). Competitive intelligence (Cl) for evaluation of construction contractors. Automation in Construction, 59, pp. 149-157. doi: 10.1016/j.autcon.2015.02.009.

Sanderson, M., Allen, P., Gill, R., \& Garnett, E. (2018) New models of contracting in the public sector: A review of alliance contracting, prime contracting and outcome-based contracting literature. Social Policy \& Administration, 52, pp. 1060-1083. https://doi.org/10.1111/spol.12322.

Sarker, B. R., Egbelu, P. J., Liao, T. W., \& Yu, J. (2012). Planning and design models for construction industry: A critical survey. Automation in Construction, 22, pp. 123-134.

Setiawan, H., Erdogan, B., \& Ogunlana, S. O. (2015). Proactiveness of contractors: A study of Indonesia. Procedia Engineering, 125, pp. 60-67. doi: 10.1016/j.proeng.2015.11.010.

Shehu, Z., \& Akintoye, A. (2010). Major challenges to the successful implementation and practice of programme management in the construction environment: A critical analysis. International Journal of Project Management, 28(1), pp. 26-39. doi: 10.1016/j.ijproman.2009.02.004.

Sinčić Ćorić, D., Anić, I.-D., Piri Rajh, S., Rajh, E., \& Kurnoga, N. (2017). Organizational buying decision approaches in manufacturing industry: Developing measures and typology. Journal of Business \& Industrial Marketing, 32(2), pp. 227-237.

Singh, M. K., Deep, S., \& Banerjee, R. (2017a). Risk management in construction projects as per Indian scenario. International Journal of Civil Engineering and Technology, 8(83), pp. 127-136.

Singh, M. K., Deep, S., \& Banerjee, R. (2017b). Risk management in construction projects as per Indian scenario. International Journal of Civil Engineering and Technology, 8(3), pp. 127-136.
Suprapto, M., Bakker, H. L. M., \& Mooi, H. G. (2015a). Relational factors in owner-contractor collaboration: The mediating role of teamworking. International Journal of Project Management, 33(6), pp. 1347-1363. doi: 10.1016/j.ijproman.2015.03.015.

Suprapto, M., Bakker, H. L. M., Mooi, H. G., \& Moree, W. (2015b). Sorting out the essence of owner-contractor collaboration in capital project delivery. International Journal of Project Management, 33(3), pp. 664-683. doi: 10.1016/j. ijproman.2014.05.001.

Wahaj, M., Deep, S., Dixit, R. B., \& Khan, M. B. (2017a). A study of project success and procurement frameworks in Indian construction industry. International Journal of Civil Engineering and Technology, 8(3), pp. 167-174.

Wahaj, M., Deep, S., Dixit, R. B., \& Khan, M. B. (2017b). A study of project success and procurement frameworks in Indian construction industry. International Journal of Civil Engineering and Technology, 8(83), pp. 167-174.

Walker, D. H., Hampson, K., \& Peters, R. (2002). Project alliancing vs project partnering: A case study of the Australian national museum project. Supply Chain Management: An International Journal, 7(2), pp. 83-91.

Wang, C. M., Xu, B. B., Zhang, S. J., \& Chen, Y. Q. (2016). Influence of personality and risk propensity on risk perception of Chinese construction project managers. International Journal of Project Management, 34(7), pp. 1294-1304. doi: 10.1016/j. ijproman.2016.07.004.

Wang, T., Tang, W., Qi, D., Shen, W., \& Huang, M. (2015). Enhancing design management by partnering in delivery of international epc projects: Evidence from Chinese construction companies. Journal of Construction Engineering and Management, 142(4), p. 04015099.

Winch, G. M. (2000). Institutional reform in British construction: Partnering and private finance. Building Research \& Information, 28(2), pp. 141-155.

Wong, C. H. (2004). Contractor performance prediction model for the United Kingdom construction contractor: Study of logistic regression approach. Journal of Construction Engineering and Management, 130(5), pp. 691-698. doi: 10.1061/(ASCE)07339364(2004)130:5(691).

Xiao, H., \& Proverbs, D. (2003). Factors influencing contractor performance: An international investigation. Engineering, Construction and Architectural Management, 10(5), pp. 322-332.

Yang, W., Gao, Y., Li, Y., Shen, H., \& Zheng, S. (2017). Different roles of control mechanisms in buyer-supplier conflict: An empirical study from China. Industrial Marketing Management, 65, pp. 144-156. doi: 10.1016/j.indmarman.2017.04.002. 


\section{Appendix 1: Ranking of delay factors and OI.}

\begin{tabular}{|c|c|c|c|c|}
\hline Rank & Groups & Factor ID & Cause of delay & Ol \\
\hline 1 & External & 43 & Delay in obtaining permission & 72.49 \\
\hline 2 & Human resources & 61 & Shortage of human resources & 72.30 \\
\hline 3 & Design & 28 & Misinterpretation of owner's requirements by design engineer & 72.03 \\
\hline 4 & External & 48 & Sudden failure actions & 71.67 \\
\hline 5 & Contractor & 10 & Inadequate contractor experience & 70.23 \\
\hline 6 & Human resources & 62 & Slow mobilization of human resources & 69.98 \\
\hline 7 & Contractor & 17 & Rework due to errors & 69.06 \\
\hline 8 & Design & 27 & Mistakes and delays in producing design documents & 68.87 \\
\hline 9 & External & 53 & Unfavourable weather conditions & 68.47 \\
\hline 10 & Project & 94 & Project ambiguities (project type, project scale, etc.) & 67.51 \\
\hline 11 & Design & 25 & Insufficient knowledge & 67.31 \\
\hline 12 & Owner & 78 & Delayed payments & 67.03 \\
\hline 13 & Material & 67 & Damage of sorted materials & 66.83 \\
\hline 14 & Owner & 85 & Slowness in decision-making & 66.78 \\
\hline 15 & Contractor & 12 & Incompetent project team & 66.76 \\
\hline 16 & Human resources & 58 & Low motivation and morale of human resources & 66.52 \\
\hline 17 & External & 46 & Global financial crisis & 66.41 \\
\hline 18 & Contractor & 13 & Ineffective project planning and scheduling & 66.30 \\
\hline 19 & Consultant & 6 & Inadequate project management assistance & 66.17 \\
\hline 20 & Project & 99 & Unfavourable contract clauses & 66.15 \\
\hline 21 & Equipment & 37 & Low efficiency of equipment & 66.07 \\
\hline 22 & Contractor & 16 & Poor site management and supervision & 66.03 \\
\hline 23 & External & 45 & Improper site facilities (water, electricity, etc.) & 65.70 \\
\hline 24 & Owner & 83 & Lack of motivation & 65.49 \\
\hline 25 & Contractor & 18 & Unreliable subcontractors & 65.33 \\
\hline 26 & Project & 95 & Inadequate definition of substantial completion & 64.55 \\
\hline 27 & Contractor & 9 & Frequent change of subcontractors & 64.48 \\
\hline 28 & Owner & 88 & Lack of financial planning & 64.46 \\
\hline 29 & Project & 97 & Conflicts between actors & 64.33 \\
\hline 30 & Equipment & 39 & Slow mobilization of equipment & 64.25 \\
\hline 31 & Owner & 89 & Long period between design and time of bidding/tendering & 64.09 \\
\hline 32 & Contractor & 15 & Communication and coordination failure & 63.84 \\
\hline 33 & Consultant & 1 & Insufficient experience on similar projects & 63.59 \\
\hline 34 & Contractor & 21 & Poor financial control on site & 63.33 \\
\hline 35 & Consultant & 8 & Communication and coordination failure & 63.21 \\
\hline 36 & Contractor & 20 & Inappropriate contractor's policies & 62.95 \\
\hline 37 & Design & 24 & Design errors due to negligence & 62.89 \\
\hline 38 & Owner & 90 & Inappropriate contractual procedure & 62.81 \\
\hline 39 & External & 56 & Thefts performed on site & 62.75 \\
\hline 40 & Consultant & 7 & Late in reviewing and approving design documents & 62.57 \\
\hline 41 & Contractor & 19 & Inadequate site investigation & 62.41 \\
\hline 42 & Owner & 86 & Suspension of work by owner & 62.21 \\
\hline 43 & External & 49 & Price fluctuations & 62.07 \\
\hline 44 & Design & 26 & Delayed approvals & 62.04 \\
\hline 45 & Human resources & 64 & Unqualified/inadequate experienced human resources & 61.72 \\
\hline 46 & External & 52 & Unexpected surface and subsurface conditions (soil, water table, etc.) & 61.68 \\
\hline 47 & Material & 68 & Delay in manufacturing materials & 60.96 \\
\hline 48 & Human resources & 65 & Human resources injuries on site & 60.95 \\
\hline 49 & Material & 73 & Shortage of construction materials & 60.94 \\
\hline 50 & External & 55 & Inappropriate government policies & 60.80 \\
\hline 51 & Design & 22 & Complexity of project design & 60.78 \\
\hline 52 & Owner & 79 & Delay in site delivery & 60.76 \\
\hline 53 & Project & 96 & Ineffective delay penalties & 60.72 \\
\hline 54 & Design & 31 & Incomplete project design & 60.70 \\
\hline
\end{tabular}




\begin{tabular}{|c|c|c|c|c|}
\hline Rank & Groups & Factor ID & Cause of delay & 이 \\
\hline 55 & Design & 23 & Frequent design changes & 60.61 \\
\hline 56 & Contractor & 14 & Obsolete technology & 60.61 \\
\hline 57 & Owner & 82 & Lack of knowledge to handle construction projects & 60.24 \\
\hline 58 & Project & 98 & Original contract duration is short & 59.67 \\
\hline 59 & Consultant & 2 & Conflict between consultant and design engineer & 59.51 \\
\hline 60 & Equipment & 34 & Frequent equipment breakdowns & 59.43 \\
\hline 61 & Owner & 93 & Selecting inappropriate contractors & 59.41 \\
\hline 62 & Equipment & 35 & Improper equipment & 59.13 \\
\hline 63 & Owner & 77 & Delay in approving design documents & 58.99 \\
\hline 64 & Owner & 81 & Lack of capable representative & 58.78 \\
\hline 65 & Contractor & 11 & Inappropriate construction methods & 58.73 \\
\hline 66 & Human resources & 59 & Low productivity of human resources & 58.71 \\
\hline 67 & Material & 66 & Variations in specification & 58.56 \\
\hline 68 & Material & 74 & Unreliable suppliers & 58.55 \\
\hline 69 & Design & 30 & Unclear and inadequate details in drawings & 58.48 \\
\hline 70 & Owner & 84 & Communication and coordination failures & 58.34 \\
\hline 71 & External & 40 & Accidents during construction & 58.15 \\
\hline 72 & Owner & 91 & Additional work & 57.88 \\
\hline 73 & Equipment & 38 & Shortage of equipment & 57.88 \\
\hline 74 & External & 54 & Inadequate production of raw material in the country & 57.87 \\
\hline 75 & Material & 70 & Late delivery of materials & 57.76 \\
\hline 76 & Material & 69 & Escalation of material prices & 57.74 \\
\hline 77 & Owner & 92 & Bureaucracy in bidding/tendering method & 57.42 \\
\hline 78 & Consultant & 3 & Delayed approval of changes by consultant & 57.37 \\
\hline 79 & Owner & 87 & Inadequate planning & 57.33 \\
\hline 80 & Human resources & 57 & Absenteeism & 57.30 \\
\hline 81 & Material & 71 & Poor procurement of construction materials & 57.23 \\
\hline 82 & Consultant & 4 & Delay in inspection and quality tests & 57.19 \\
\hline 83 & External & 50 & Problem with neighbours & 57.10 \\
\hline 84 & Equipment & 33 & Equipment allocation problem & 57.03 \\
\hline 85 & Owner & 76 & Conflicts between joint ownership & 56.74 \\
\hline 86 & External & 44 & Delay in third-party inspection and certification & 56.51 \\
\hline 87 & Design & 32 & Defective design made by designers & 56.50 \\
\hline 88 & Owner & 80 & Improper project feasibility study & 55.61 \\
\hline 89 & External & 42 & Different tactics patterns for bribes & 55.61 \\
\hline 90 & Material & 72 & Poor quality of construction materials & 55.25 \\
\hline 91 & Design & 29 & Lack of application of software & 54.88 \\
\hline 92 & External & 47 & Time losses due to interruption & 54.84 \\
\hline 93 & External & 51 & Slow site clearance & 53.56 \\
\hline 94 & Equipment & 36 & Inadequate modern equipment & 53.51 \\
\hline 95 & External & 41 & Changes in government regulations and laws & 52.44 \\
\hline 96 & Consultant & 5 & Inaccurate site investigation & 52.43 \\
\hline 97 & Human resources & 60 & Personal conflicts amongst human resources & 52.08 \\
\hline 98 & Owner & 75 & Modifications & 51.04 \\
\hline 99 & Human resources & 63 & Human resources strike due to revolutions & 48.82 \\
\hline
\end{tabular}

Ol, overall index. 